\title{
Interactions between uptake of amino acids and inorganic nitrogen in wheat plants
}

\author{
E. Gioseffi, A. de Neergaard, and J. K. Schjoerring \\ Plant and Soil Science Section, Department of Agriculture and Ecology, Faculty of Life Sciences, University of Copenhagen, \\ Thorvaldsensvej 40, 1871 Frederiksberg C, Denmark
}

Correspondence to: J. K. Schjoerring (jks@life.ku.dk)

Received: 29 October 2011 - Published in Biogeosciences Discuss.: 24 November 2011

Revised: 26 March 2012 - Accepted: 10 April 2012 - Published: 24 April 2012

\begin{abstract}
Soil-borne amino acids may constitute a source of nitrogen $(\mathrm{N})$ for plants in various terrestrial ecosystems but their importance for total $\mathrm{N}$ nutrition is unclear, particularly in nutrient-rich arable soils. One reason for this uncertainty is lack of information on how the absorption of amino acids by plant roots is affected by the simultaneous presence of inorganic $\mathrm{N}$ forms. The objective of the present study was to study absorption of glycine (Gly) and glutamine (Gln) by wheat roots and their interactions with nitrate $\left(\mathrm{NO}_{3}^{-}\right)$and ammonium $\left(\mathrm{NH}_{4}^{+}\right)$during uptake. The underlying hypothesis was that amino acids, when present in nutrient solution together with inorganic $\mathrm{N}$, may lead to down-regulation of the inorganic $\mathrm{N}$ uptake, thereby resulting in similar total $\mathrm{N}$ uptake rates. Amino acids were enriched with double-labelled ${ }^{15} \mathrm{~N}$ and ${ }^{13} \mathrm{C}$, while $\mathrm{NO}_{3}^{-}$and $\mathrm{NH}_{4}^{+}$acquisition was determined by their rate of removal from the nutrient solution surrounding the roots. The uptake rates of $\mathrm{NO}_{3}^{-}$and $\mathrm{NH}_{4}^{+}$did not differ from each other and were generally about twice as high as the uptake rate of organic $\mathrm{N}$ when the different $\mathrm{N}$ forms were supplied separately in concentrations of $2 \mathrm{mM}$. Nevertheless, replacement of $50 \%$ of the inorganic $\mathrm{N}$ with organic $\mathrm{N}$ was able to restore the $\mathrm{N}$ uptake to the same level as that in the presence of only inorganic $\mathrm{N}$. Co-provision of $\mathrm{NO}_{3}^{-}$did not affect glycine uptake, while the presence of glycine down-regulated $\mathrm{NO}_{3}^{-}$uptake. The ratio between ${ }^{13} \mathrm{C}$ and ${ }^{15} \mathrm{~N}$ were lower in shoots than in roots and also lower than the theoretical values, reflecting higher $\mathrm{C}$ losses via respiratory processes compared to $\mathrm{N}$ losses. It is concluded that organic $\mathrm{N}$ can constitute a significant $\mathrm{N}$-source for wheat plants and that there is an interaction between the uptake of inorganic and organic $\mathrm{N}$.
\end{abstract}

\section{Introduction}

Amino acids are ubiquitously present in the soil solution and may constitute a significant source of $\mathrm{N}$ for plants in terrestrial ecosystems. The concentration of amino acids in the soil solution ranges from 0.1 to $60 \mu \mathrm{M}$ and typically constitutes $10-40 \%$ of the total soluble N (Hill et al., 2011; Jamtgard et al., 2008; Jones et al., 2002). The pool of dissolved amino acids is supplemented by a substantial pool of absorbed amino acids which can be up to 50 times higher than the amount of free amino acids and, in unfertilized soils, even higher than the content of ammonium and nitrate (Jamtgard et al., 2010). In cropping systems which rely on recycling and decomposition of organic $\mathrm{N}$ sources (e.g. animal manure based, low-input or organic agriculture), amino acids may represent a large $\mathrm{N}$ input (El-Naggar et al., 2009) and an important plant-available N pool (Jones et al., 2002). Under such circumstances, a significant proportion of total $\mathrm{N}$ in the soil solution consists of dissolved organic $\mathrm{N}$, including both free amino acids and complex, humic-rich soluble organic matter which has relatively low bioavailability (Christou et al., 2005). The distribution of free amino acids in soil may show considerable spatial heterogeneity due to, e.g. degradation of sloughed-off root cell in the rhizosphere, leading to hotspots with greatly higher concentrations than in the bulk soil (Jones et al., 2002). The fast turnover of amino acids in soils implies that soil solution pool can be continuously renewed and, hence, provide the basis for significant plant uptake despite a low concentration in soil solution (Thornton and Robinson, 2005). 
Amino acids may constitute a significant part of the $\mathrm{N}$ absorbed by plants in terrestrial ecosystems, especially under low N conditions (Harrison et al., 2000; Nasholm et al., 1998, 2000, 2009; Persson and Nasholm, 2002). Several amino acid transporters have been described in plants, conferring ability to absorb amino acids from the soil solution (Lipson and Nasholm, 2001). In Arabidopsis roots, the three amino acid transporters AAP1, AAP5 and LHT1 have been shown to play a role in amino acid uptake. They each have different specificity and affinity for amino acids (Hirner et al., 2006; Lee et al., 2007; Svennerstam et al., 2008). Amino acid transporters are less well characterised in other species but it is well documented that amino acid uptake occurs in a wide range of species including gymnosperms (Nasholm et al., 1998; Persson and Nasholm, 2002), dicots (Ge et al., 2009; Kielland, 1994; Nasholm et al., 1998, 2000; Streeter et al., 2000) and monocots (Biernath et al., 2008; El-Naggar et al., 2009; Henry and Jefferies, 2003; Jamtgard et al., 2008, 2010; Kielland, 1994; Lipson et al., 1999; Nasholm et al., 1998, 2000, 2001; Nasholm and Persson, 2001; Schimel and Chapin, 1996; Streeter et al., 2000; Thornton, 2001; Thornton and Robinson, 2005; Yamagata and Ae, 1999). However, the importance and significance of organic $\mathrm{N}$ as a source of crop $\mathrm{N}$ under different management systems is still not well established.

One aspect causing uncertainty about the importance of organic $\mathrm{N}$ compounds as $\mathrm{N}$ source for plants is the possible interaction between organic and inorganic $\mathrm{N}$ forms during absorption by plant roots (Thornton and Robinson, 2005). The existing knowledge about these interactions is mainly based on experimental approaches in which plants have been pretreated with amino acids and subsequently exposed to $\mathrm{NO}_{3}^{-}$ or $\mathrm{NH}_{4}^{+}$or vice-versa (e.g. Persson and Nasholm, 2002). In most cases, inorganic $\mathrm{N}$ absorption is down-regulated following pre-treatment with amino acids, although the actual responses are quite variable and may also depend on the $\mathrm{N}$ form used during the pre-treatment (Thornton, 2004). Less information is available from experiments in which inorganic and organic $\mathrm{N}$ forms have been supplied together. Using ${ }^{14} \mathrm{C} /{ }^{13} \mathrm{C} /{ }^{15} \mathrm{~N}$ triple-labelling instead of the double ${ }^{15} \mathrm{~N}-{ }^{13} \mathrm{C}$ or ${ }^{15} \mathrm{~N}-{ }^{14} \mathrm{C}$ labelling classically used for direct root uptake experiments, Rasmussen and Kuzyakov (2009) and Rasmussen et al. (2010) recently showed that the simultaneous uptake of inorganic $\mathrm{C}$ derived from mineralization of organic compounds interfered with root uptake of dual-labelled organic $\mathrm{N}$. It will be of similar importance to assess the interactions between organic and inorganic forms during absorption by plant roots in order to establish the significance of organic $\mathrm{N}$ compounds for plant $\mathrm{N}$ nutrition.

The purpose of the present work was to evaluate interactions between the amino acids glycine and glutamine and the inorganic $\mathrm{N}$ forms nitrate and ammonium during uptake by plant roots. The underlying hypothesis was that amino acids, when co-present in nutrient solution with inorganic nitrogen, may lead to a down-regulation of inorganic $\mathrm{N}$ uptake or viceversa, thereby resulting in similar total $\mathrm{N}$ uptake rates. A series of experiments was conducted in which double labelled $\left({ }^{15} \mathrm{~N}-{ }^{13} \mathrm{C}\right)$ amino acids applied to wheat plants were used to trace amino acid absorption, while the net-uptake rate of inorganic $\mathrm{N}$ was determined by regular sampling and analysis of the nutrient solution.

\section{Materials and methods}

Three independent experiments were carried out as detailed below. The purpose of Experiment I was to test the hypothesis that partial substitution of an inorganic $\mathrm{N}$ source $\left(\mathrm{NO}_{3}^{-}\right.$or $\mathrm{NH}_{4}^{+}$) with an organic form (glycine or glutamine) would be able to restore the total $\mathrm{N}$ uptake to the same level as that in the presence of only inorganic N. In Experiment II the objective was to test how organic $\mathrm{N}$ (glycine) affected inorganic $\mathrm{N}\left(\mathrm{NO}_{3}^{-}\right)$uptake, and vice-versa, when the concentration of each of the two sources was the same whether supplied alone or in mixture (i.e. increasing total $\mathrm{N}$ concentration when the two sources were applied together). Finally, the purpose of Experiment III was to test the hypothesis that plants were able to sustain growth and $\mathrm{N}$ acquisition when inorganic $\mathrm{N}\left(\mathrm{NO}_{3}^{-}\right)$was completely replaced by an organic $\mathrm{N}$ source (glycine, glutamine, arginine or asparagine).

\subsection{Plant cultivation and harvest}

\subsubsection{Experiment I}

Spring wheat (Triticum aestivum L. cv. Amaretto) was germinated in vermiculite for 10 days at $27^{\circ} \mathrm{C}$. Uniform seedlings were transferred to 40 opaque 41 cultivation units each holding 4 plants. The units were filled with aerated basic nutrient solution having the following composition: $0.2 \mathrm{mM} \quad \mathrm{KH}_{2} \mathrm{PO}_{4}, \quad 0.2 \mathrm{mM}$ $\mathrm{K}_{2} \mathrm{SO}_{4}, 0.3 \mathrm{mM} \mathrm{MgSO} 4 \cdot 7 \mathrm{H}_{2} \mathrm{O}, 0.1 \mathrm{mM} \mathrm{NaCl}, 0.1 \mathrm{mM}$ $\mathrm{Mg}\left(\mathrm{NO}_{3}\right)_{2} \cdot 6 \mathrm{H}_{2} \mathrm{O}, \quad 0.7 \mathrm{mM} \quad \mathrm{Ca}\left(\mathrm{NO}_{3}\right)_{2} \cdot 4 \mathrm{H}_{2} \mathrm{O}, \quad 0.4 \mathrm{mM}$ $\mathrm{KNO}_{3}, 0.8 \mu \mathrm{M} \mathrm{Na} 2 \mathrm{MoO}_{4} \cdot 2 \mathrm{H}_{2} \mathrm{O}, 0.7 \mu \mathrm{M} \mathrm{ZnCl} 2,0.8 \mu \mathrm{M}$ $\mathrm{CuSO}_{4} \cdot 5 \mathrm{H}_{2} \mathrm{O}, 2 \mu \mathrm{M} \mathrm{H}_{2} \mathrm{BO}_{3}, 1 \mu \mathrm{M} \mathrm{NiSO} \cdot 6 \mathrm{H}_{2} \mathrm{O}, 50 \mu \mathrm{M}$ $\mathrm{Fe}\left(\mathrm{NO}_{3}\right)_{3} \cdot 9 \mathrm{H}_{2} \mathrm{O}$, and $10 \mathrm{mM}$ EDTA. The plants were grown in a greenhouse with controlled environment at 250 to $280 \mu \mathrm{mol} \mathrm{m}{ }^{-2} \mathrm{~s}^{-1}$ photon flux density and a $18^{\circ} \mathrm{C} / 16^{\circ} \mathrm{C}$ day/night $(16 / 8 \mathrm{~h})$ temperature regime. The nutrient solution was replaced every week and the position of the cultivation units shifted to minimize differences in growth due to micro-environmental differences.

After 30 days in the basic nutrient solution, plants from 4 cultivation units (16 individual plants) were harvested while the remaining 36 units were allocated to nine different nitrogen treatments. The nitrogen treatments lasted for $60 \mathrm{~h}$ and consisted of (i) $2 \mathrm{mM}$ glycine (Gly), (ii) $2 \mathrm{mM}$ glutamine (Gln), (iii) $1 \mathrm{mM} \mathrm{Gly}+1 \mathrm{mM} \mathrm{NO}_{3}^{-}$, (iv) $1 \mathrm{mM} \mathrm{Gln}+1 \mathrm{mM}$ $\mathrm{NO}_{3}^{-}$, (v) $1 \mathrm{mM} \mathrm{Gly}+1 \mathrm{mM} \mathrm{NH}_{4}^{+}$, (vi) $1 \mathrm{mM} \mathrm{Gln}+1 \mathrm{mM}$ 
$\mathrm{NH}_{4}^{+}$; (vii) $2 \mathrm{mM} \mathrm{NO}-$; (viii) $2 \mathrm{mM} \mathrm{NH}_{4}^{+}$; (ix) no nitrogen $\left(\mathrm{N}_{0}\right)$ with four replicates. Amino acids were enriched by 1.37 atom \% with double-labelled ${ }^{15} \mathrm{~N}$ and ${ }^{13} \mathrm{C}$ (Icon Services Inc., New York, USA). Both the amide and amine $\mathrm{N}$ atom in Gln were ${ }^{15} \mathrm{~N}$ labelled. Ammonium was supplied as $\left(\mathrm{NH}_{4}\right)_{2} \mathrm{SO}_{4}$ and nitrate as $\mathrm{KNO}_{3}$. The other plant nutrients were provided at the same concentrations as in the basic nutrient solution except for $\mathrm{Ca}^{2+}$ and $\mathrm{SO}_{4}^{2-}$ which were used to obtain cation-anion balance. The $\mathrm{pH}$ in the nutrient solution was maintained around 5.5 by use of calcium hydroxide or sulphuric acid every $12 \mathrm{~h}$. Twenty $\mathrm{ml}$ samples of the nutrient solution were taken from each cultivation unit at 4 time points, viz. $0,22,45$ and $60 \mathrm{~h}$ after beginning of the treatment period. Plants were harvested by the end of the $60 \mathrm{~h}$ experimental period.

\subsubsection{Experiment II}

Wheat plants were pre-grown for 30 days under the same conditions as above. Plants were then subjected to addition of $1 \mathrm{mM}$ glycine and $3 \mathrm{mM} \mathrm{NO}_{3}^{-}$or $1 \mathrm{mM}$ glycine alone (4 replicates). Prior to the $\mathrm{N}$ treatments, 4 groups with each 4 plants had not received $\mathrm{N}$ for 3 days ( $\mathrm{N}$ starvation treatment). The glycine was $10 \%$ enriched with double-labelled ${ }^{15} \mathrm{~N}$ and ${ }^{13} \mathrm{C}$. $\mathrm{N}$ uptake from glycine and $\mathrm{NO}_{3}^{-}$was then measured over 3 days.

\subsubsection{Experiment III}

Under the same light and temperature conditions as Experiments I and II, wheat plants were grown for 7 days in complete nutrient solutions with $\mathrm{NO}_{3}^{-}$as the sole $\mathrm{N}$ source followed by a 17 day period in which $1 \mathrm{mM}$ unlabelled glycine, glutamine, arginine, asparagine or $3 \mathrm{mM} \mathrm{NO}_{3}^{-}$were provided as the only $\mathrm{N}$ source (4 replicates).

\subsection{Analysis of plants and nutrient solution}

At harvest, the plant material in each cultivation unit were quickly separated into roots and shoots which were weighed, frozen in liquid $\mathrm{N}$ and stored at $-80^{\circ} \mathrm{C}$. Prior to analysis all plant material was freeze-dried until constant weight and milled to $<0.5 \mathrm{~mm}$. The dried samples were subsequently used for analyzing total $\mathrm{C},{ }^{13} \mathrm{C} /{ }^{12} \mathrm{C}$, total $\mathrm{N}$ and ${ }^{15} \mathrm{~N} /{ }^{14} \mathrm{~N}$ by mass spectrometry in a system consisting of an ANCA-SL elemental analyzer coupled to a 20-20 tracermass mass spectrometer (SerCon Ltd., Crewe, UK).

All samples of nutrient solutions were analysed for $\mathrm{NO}_{3}^{-}$ and $\mathrm{NH}_{4}^{+}$using flow injection analysis (Lachat 8000 series, Hach, Loveland, Colorado). ${ }^{15} \mathrm{NH}_{4}^{+},{ }^{15} \mathrm{NO}_{3}^{-}$and total $\mathrm{N}$ were in selected cases measured by mass spectrometry following the micro-diffusion technique (Brooks et al., 1989). In order to double check the recovery of amino acids in solution, CF-IRMS analyses of the nutrient solutions sampled at the completion of the experiments were performed after oven-drying at $50^{\circ} \mathrm{C}$.

\subsection{Calculations}

$\mathrm{N}$ recoveries and $\mathrm{N}$ uptake rates were calculated on the basis of excess ${ }^{15} \mathrm{~N}$ and ${ }^{13} \mathrm{C}$ in the harvested plant material combined with the concentrations of $\mathrm{N}$ left in the nutrient solution.

$\mathrm{N}$ and $\mathrm{C}$ atom $\%$ excess was calculated as excess compared to the mean atom $\%$ of the pre-treatment plants, according to the equation:

$\mathrm{APE}=\mathrm{AP}_{\mathrm{p}}-\mathrm{AP}_{\mathrm{ptp}}$

where $\mathrm{APE}=$ atom percent excess, $\mathrm{AP}_{\mathrm{p}}=$ atom percent in treated plant, and $\mathrm{AP}_{\mathrm{ptp}}=$ atom percent in pre-treatment plants (average).

The amount of amino-acid derived ${ }^{15} \mathrm{~N}$ or ${ }^{13} \mathrm{C}$ taken up by the plant was calculated by use of Eq. (2):

$\mathrm{AA}-{ }^{15} \mathrm{~N}=\mathrm{DW} \times \mathrm{N} \% \times \operatorname{APE}(\mathrm{N})$

where $\mathrm{AA}-{ }^{15} \mathrm{~N}=$ amino acid-derived ${ }^{15} \mathrm{~N}$ in plant tissue $(\mathrm{mg}), \mathrm{DW}=$ plant dry weight $(\mathrm{mg}), \mathrm{N} \%=$ plant nitrogen concentration $\left(\mathrm{mg} \mathrm{mg}^{-1}\right)$, and $\mathrm{APE}(\mathrm{N})=$ nitrogen atom percentage excess $\left(\mathrm{mg} \mathrm{mg}^{-1}\right)$.

Recovery of the added amino acids in plant material was calculated by use of Eq. (3):

$R_{\mathrm{N}}=\frac{\mathrm{AA}^{-15} \mathrm{~N}}{\mathrm{AA}^{15} \mathrm{~N}_{\mathrm{add}}} \times 100$

where $R_{\mathrm{N}}=\mathrm{N}$ recovery in plant $(\%)$ and $\mathrm{AA}^{-15} \mathrm{~N}_{\text {add }}=$ added amino acid- ${ }^{15} \mathrm{~N}(\mathrm{mg})$.

For inorganic N, the uptake rate was calculated based on the $\mathrm{N}$ left in solution according to Eq. (4), and for organic $\mathrm{N}$ based on the ${ }^{15} \mathrm{~N}$ excess in plant material after harvest, according to Eq. (5):

$\mathrm{UR}_{\text {inorgN }}=\frac{\left(\mathrm{N}_{\text {left. } T_{2}}-\mathrm{N}_{\text {left. } T_{1}}\right)}{\mathrm{DW}_{\text {root }} \times\left(T_{2}-T_{1}\right)}$

$\mathrm{UR}_{\mathrm{orgN}}=\frac{\mathrm{AA}^{-15} \mathrm{~N}}{\mathrm{DW}_{\text {root }} \times T 2}$

where $\mathrm{UR}=$ uptake rate and $T_{2}, T_{1}=$ sampling times $(\mathrm{h}$ after start of treatments). All calculations of $\mathrm{NO}_{3}^{-}$and $\mathrm{NH}_{4}^{+}$uptake rates were based on the initial linear part of the depletion curves extending up to $45 \mathrm{~h}$ after start of the experiment.

\subsection{Statistical analysis}

Statistical analysis was carried out using $\mathrm{R}$ version 2.12 .2 (www.r-project.org) through mixed linear model comparisons and analysis of variance followed by Tukey's and Duncan's test. The model comparisons were based on pair-wise analysis of variance between two statistical models. Whenever two compared models were statistically different $(95 \%$ confidence interval), the model with higher complexity was accepted. 


\section{Results}

\section{1 $\mathrm{N}$ content and ${ }^{13} \mathrm{C}:{ }^{15} \mathrm{~N}$ ratio}

${ }^{15} \mathrm{~N}$ and ${ }^{13} \mathrm{C}$ excess increased in plants supplied with amino acids (Table 1). The excess of the two stable isotopes was almost twice as high in plants receiving organic $\mathrm{N}(2 \mathrm{mM}$ Gly or Gln) as the sole $\mathrm{N}$ supply compared to plants receiving only half the concentration of organic N (1 mM Gly or Gln) in combination with inorganic $\mathrm{N}\left(1 \mathrm{mM} \mathrm{NH}_{4}^{+}\right.$or $\left.\mathrm{NO}_{3}^{-}\right)$. The $\mathrm{N}$ treatments did not affect the dry matter weight of the plants which on average was $2.7 \pm 0.1 \mathrm{~g} \mathrm{plant}^{-1}(P>0.05$; data not shown). Similarly, the $\mathrm{N}$ concentration in the plant dry matter and the total $\mathrm{N}$ content did not differ $(P>0.05)$ among $\mathrm{N}$ fed plants irrespective of in which form the $\mathrm{N}$ was supplied (Table 1).

The ratio between ${ }^{13} \mathrm{C}$ and ${ }^{15} \mathrm{~N}$ recovered in the plant tissues was lower than the theoretical values of 2.5:1 for glutamine and 2:1 for glycine in all plants receiving organic $\mathrm{N}$ (Fig. 1). The ${ }^{13} \mathrm{C}:{ }^{15} \mathrm{~N}$ ratio was in all cases lower in shoots than in roots $(P \leq 0.05)$. Plants receiving glutamine as the sole $\mathrm{N}$ supply had higher ${ }^{13} \mathrm{C}:{ }^{15} \mathrm{~N}$ ratio in the roots than plants supplied with glycine, reflecting the higher $\mathrm{C}: \mathrm{N}$ ratio of glutamine. However, the opposite was the case for shoots, showing higher ${ }^{13} \mathrm{C}:{ }^{15} \mathrm{~N}$ ratio for plants receiving glycine relative to glutamine (Fig. 1). Irrespective of the amino acid supplied, shoot ${ }^{13} \mathrm{C}:{ }^{15} \mathrm{~N}$ ratios were higher in plants receiving $\mathrm{NH}_{4}^{+}$compared to $\mathrm{NO}_{3}^{-}(P \leq 0.05)$.

\subsection{N uptake rates}

The uptake rates of $\mathrm{NO}_{3}^{-}$and $\mathrm{NH}_{4}^{+}$did not differ from each other and were generally about twice as high as the uptake rate of organic $\mathrm{N}$ when the different $\mathrm{N}$ forms were supplied separately in concentrations of $2 \mathrm{mM}$, with the exception of glycine and $\mathrm{NH}_{4}^{+}$(Fig. 2). Nevertheless, replacement of $50 \%$ of the inorganic $\mathrm{N}$ with organic $\mathrm{N}$ was able to restore the $\mathrm{N}$ uptake to the same level as that in the presence of only inorganic N (Fig. 2).

Significantly different amino acid uptake rates were obtained depending on whether ${ }^{13} \mathrm{C}$ or ${ }^{15} \mathrm{~N}$ were used for the calculations (Fig. 3). In all cases, ${ }^{13} \mathrm{C}$-based uptake rates were much lower than those based on ${ }^{15} \mathrm{~N}$.

\subsection{Interactions between $\mathbf{N}$ forms}

The model-comparison statistical analysis of the data in Fig. 2 showed a significant interaction between the uptake of organic and inorganic $N(P \leq 0.05)$. Such interaction was also evident in Experiment II, where co-provision of $\mathrm{NO}_{3}^{-}$did not affect glycine uptake, while the presence of glycine down-regulated $\mathrm{NO}_{3}^{-}$uptake (Fig. 4). Pre-starvation of plants did not lead to increased uptake of glycine (Fig. 4).

Plants exposed to glycine as the sole $\mathrm{N}$ form after precultivation on nitrate had lower $\mathrm{NO}_{3}^{-}$concentrations in roots as well as shoots compared to plants continuously receiving

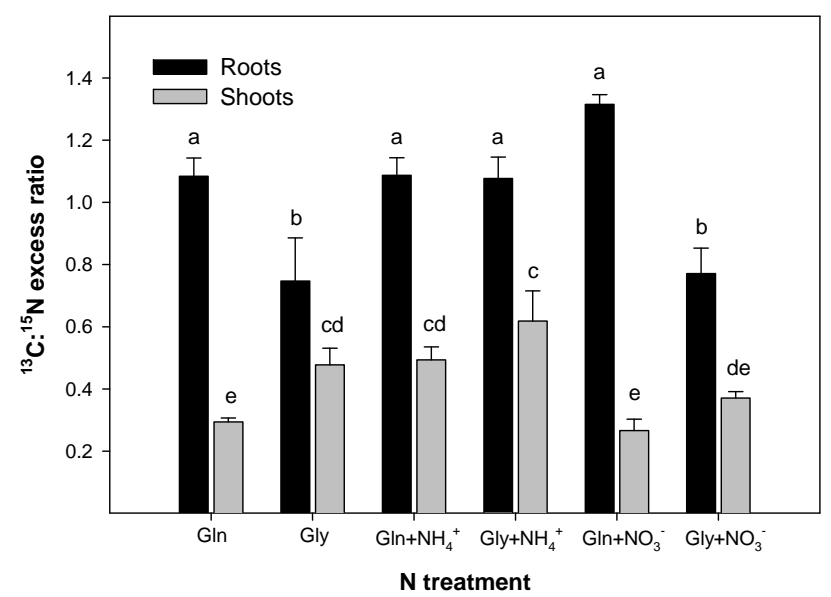

Fig. 1. Ratio between ${ }^{13} \mathrm{C}:{ }^{15} \mathrm{~N}$ excess in roots and shoots of wheat plants supplied with double-labelled amino acids, either alone or mixed with inorganic $\mathrm{N}$. Values are means $\pm \operatorname{SE}(n=4)$ obtained in Experiment I and letters indicate significant differences at $P=0.05$ (Duncan test).

$\mathrm{NO}_{3}^{-}$(Fig. 5). Pre-starvation also led to a reduction in tissue $\mathrm{NO}_{3}^{-}$(Fig. 5). Tissue $\mathrm{NH}_{4}^{+}$concentrations were similar across the different $\mathrm{N}$ treatments (Fig. 5).

\section{4 $\mathrm{N}$ and $\mathrm{C}$ recovery in wheat plants}

About $70-80 \%$ of the added amino-acid-N was recovered in the plants. In all cases, at plant harvest there was still a small fraction of $\mathrm{N}$ left in the solutions containing amino acids (Fig. 6). Labelled ${ }^{15} \mathrm{NH}_{4}^{+}$was detected in some of the originally pure amino acid solutions, indicating possible deamination by microorganisms in solution or efflux of ${ }^{15} \mathrm{NH}_{4}^{+}$from the roots. However, deamination prior to uptake did not seem prominent as evidenced by the fact that when plants in Experiment III were grown for an extended period with amino acids as the sole $\mathrm{N}$ source, plant growth was reduced by $50 \%$ or more compared to plants grown in $\mathrm{NO}_{3}^{-}$(Fig. 7).

\section{Discussion}

\subsection{Interaction between organic and inorganic $\mathrm{N}$ forms}

Inorganic nitrogen is considered to be the preferred $\mathrm{N}$ form taken up by higher plants. This was also the case in the present study, as shown by generally higher uptake rates of $\mathrm{NO}_{3}^{-}$and $\mathrm{NH}_{4}^{+}$compared to amino acids when the total $\mathrm{N}$ concentration was the same (i.e. $2 \mathrm{mM}$; Fig. 2). Compared across experiments, the uptake rate of glycine in wheat roots seemed only to respond marginally to an increase in external concentration, being similar at $1 \mathrm{mM}$ (Fig. 4) and $2 \mathrm{mM}$ (Fig. 2) when glycine was supplied as the sole $\mathrm{N}$ source. In contrast, the uptake of $\mathrm{NO}_{3}^{-}$was higher at $3 \mathrm{mM}$ (around $28 \mu \mathrm{mol} \mathrm{g}^{-1}$ root DW h${ }^{-1}$; Fig. 4) compared 
Table 1. $\mathrm{N}$ concentration and total $\mathrm{N}$ content of plants in Experiment I. Numbers are mean values $(n=4)$. Letters indicate significant differences at $P=0.05$ (Tukey's test). Within columns, values followed by the same letter are not significantly different. Excess $15 \mathrm{~N} \%$ and ${ }^{13} \mathrm{C} \%$ values were calculated taking the $\mathrm{N}_{0}$ treatment as reference $\left({ }^{15} \mathrm{~N} \%=0.3706\right.$ for roots and 0.3681 for shoots; ${ }^{13} \mathrm{C} \%=1.0786$ for roots and 0.0773 for shoots).

\begin{tabular}{|c|c|c|c|c|c|c|}
\hline \multirow[b]{2}{*}{ Treatment } & \multirow[b]{2}{*}{$\begin{array}{l}\mathrm{N} \text { conc. } \\
\%\end{array}$} & \multirow[b]{2}{*}{$\begin{array}{l}\text { N content } \\
\text { g plant }^{-1}\end{array}$} & \multicolumn{2}{|c|}{$\mathrm{N}$ excess } & \multicolumn{2}{|c|}{ C excess } \\
\hline & & & $\begin{array}{l}\text { Root } \\
\%\end{array}$ & $\begin{array}{l}\text { Shoot } \\
\%\end{array}$ & $\begin{array}{l}\text { Root } \\
\% o\end{array}$ & $\begin{array}{l}\text { Shoot } \\
\% 0\end{array}$ \\
\hline Pre-treated & $4.50 \mathrm{a}$ & $0.09 \mathrm{a}$ & NA & NA & NA & NA \\
\hline $\mathrm{NH}_{4}^{+}$ & $4.35 \mathrm{a}$ & $0.12 \mathrm{ab}$ & $-0.002 \mathrm{c}$ & $0.000 \mathrm{c}$ & $0.000 \mathrm{~d}$ & $0.000 \mathrm{~d}$ \\
\hline $\mathrm{NO}_{3}^{-}$ & $4.10 \mathrm{a}$ & $0.13 \mathrm{~b}$ & $-0.002 \mathrm{c}$ & $0.000 \mathrm{c}$ & $0.002 \mathrm{~d}$ & $0.001 \mathrm{~d}$ \\
\hline Gln & $3.89 \mathrm{ab}$ & $0.13 \mathrm{~b}$ & $0.413 \mathrm{a}$ & $0.184 \mathrm{a}$ & $0.408 \mathrm{a}$ & $0.055 \mathrm{~b}$ \\
\hline Gly & $4.02 \mathrm{a}$ & $0.12 \mathrm{ab}$ & $0.425 \mathrm{a}$ & $0.210 \mathrm{a}$ & $0.272 \mathrm{bc}$ & $0.100 \mathrm{a}$ \\
\hline $\mathrm{Gln}+\mathrm{NH}_{4}^{+}$ & $4.11 \mathrm{a}$ & $0.12 \mathrm{ab}$ & $0.208 \mathrm{~b}$ & $0.104 \mathrm{~b}$ & $0.227 \mathrm{bc}$ & $0.054 \mathrm{~b}$ \\
\hline $\mathrm{Gly}+\mathrm{NH}_{4}^{+}$ & $3.70 \mathrm{ab}$ & $0.11 \mathrm{ab}$ & $0.173 \mathrm{~b}$ & $0.101 \mathrm{~b}$ & $0.169 \mathrm{c}$ & $0.058 \mathrm{~b}$ \\
\hline $\mathrm{Gln}+\mathrm{NO}_{3}^{-}$ & $3.94 \mathrm{ab}$ & $0.12 \mathrm{ab}$ & $0.229 \mathrm{~b}$ & $0.097 \mathrm{~b}$ & $0.304 \mathrm{ab}$ & $0.026 \mathrm{c}$ \\
\hline $\mathrm{Gly}+\mathrm{NO}_{3}^{-}$ & $4.06 \mathrm{a}$ & $0.11 \mathrm{ab}$ & $0.242 \mathrm{~b}$ & $0.117 \mathrm{~b}$ & $0.183 \mathrm{c}$ & $0.048 \mathrm{~b}$ \\
\hline $\mathrm{N}_{0}$ & $3.19 \mathrm{~b}$ & $0.10 \mathrm{ab}$ & $0.000 \mathrm{c}$ & $0.000 \mathrm{c}$ & $0.000 \mathrm{~d}$ & $0.000 \mathrm{~d}$ \\
\hline
\end{tabular}

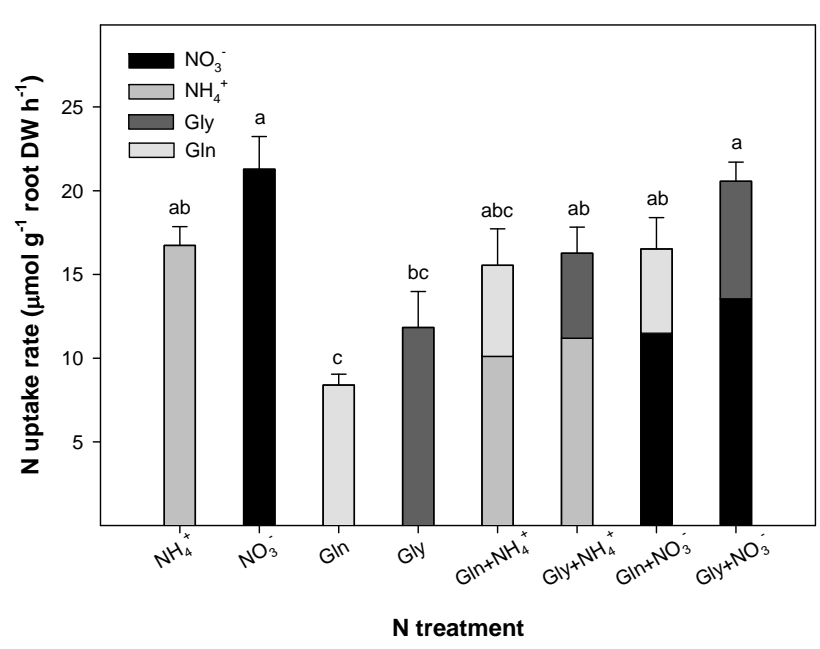

Fig. 2. Mean $N$ uptake rates in wheat plants supplied with different combinations of amino acids and inorganic $\mathrm{N}$ forms in Experiment I. For inorganic-N, values were calculated on the basis of the $\mathrm{N}$ remaining in solution, while for amino acid- $\mathrm{N}$ values were calculated based on ${ }^{15} \mathrm{~N}$ content in plants. All treatments had a total $\mathrm{N}$ concentration of $2 \mathrm{mM}$. Data are means, error bars indicate cumulative $\pm \mathrm{SE}(n=4)$, and letters indicate significant differences at $P=0.05$ (Tukey's test).

to $2 \mathrm{mM}$ (around $23 \mu \mathrm{molg}^{-1} \operatorname{rootDWh} \mathrm{DW}^{-1}$; Fig. 2). Assuming that $\mathrm{NO}_{3}^{-}$uptake responds linearly to changes in the external $\mathrm{NO}_{3}^{-}$concentration in the low-affinity range (Glass, 2009) this would imply a net uptake rate of around $18 \mu \mathrm{mol} \mathrm{g}^{-1}$ root DW h${ }^{-1}$ at $1 \mathrm{mM}$ external $\mathrm{NO}_{3}^{-}$. The actual observed uptake rate of $\mathrm{NO}_{3}^{-}$in solutions containing $1 \mathrm{mM} \mathrm{NO}_{3}^{-}$in the presence of $1 \mathrm{mM}$ glycine was only around $13 \mu \mathrm{molg}^{-1} \operatorname{root~DWh}^{-1}$ (Fig. 2), indicating that

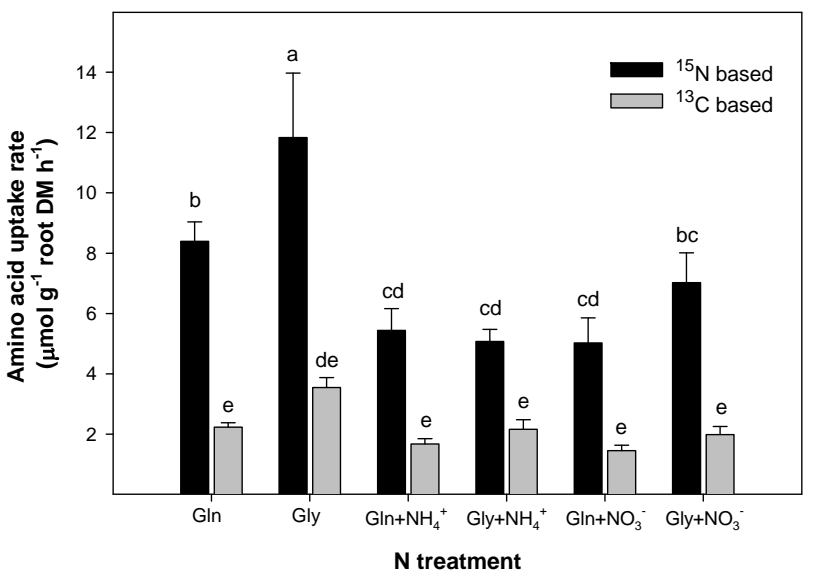

Fig. 3. Amino acid uptake rates calculated on the basis of either ${ }^{15} \mathrm{~N}$ or ${ }^{13} \mathrm{C}$ data in Experiment I. Data are means $\pm \mathrm{SE}(n=4)$ and letters indicate significant differences at $P=0.05$.

$\mathrm{NO}_{3}^{-}$uptake was down-regulated. This conclusion based on data from Experiment I is corroborated by the data obtained in Experiment II, showing that co-provision of $1 \mathrm{mM}$ glycine and $3 \mathrm{mM} \mathrm{NO}_{3}^{-}$resulted in a down-regulation of $\mathrm{NO}_{3}^{-}$uptake while that of glycine was unaffected (Fig. 4). Since glycine uptake is not down-regulated in the presence of $\mathrm{NO}_{3}^{-}$, plants may be able to maintain a similar total $\mathrm{N}$ uptake as when $\mathrm{NO}_{3}^{-}$constitutes their sole $\mathrm{N}$ source, as shown by the fact that replacement of $50 \%$ of the inorganic $\mathrm{N}$ with organic $\mathrm{N}$ in Experiment $\mathrm{I}$ was able to restore the $\mathrm{N}$ uptake rate to the same level as that in the presence of only inorganic N (Fig. 2). Plants may thus be able to fulfil their $\mathrm{N}$ requirement when organic $\mathrm{N}$ is provided as an $\mathrm{N}$ source in mixture with $\mathrm{NO}_{3}^{-}$. Ammonium has been reported to cause down-regulation of amino acid uptake and vice-versa (Henry and Jefferies, 2003; 

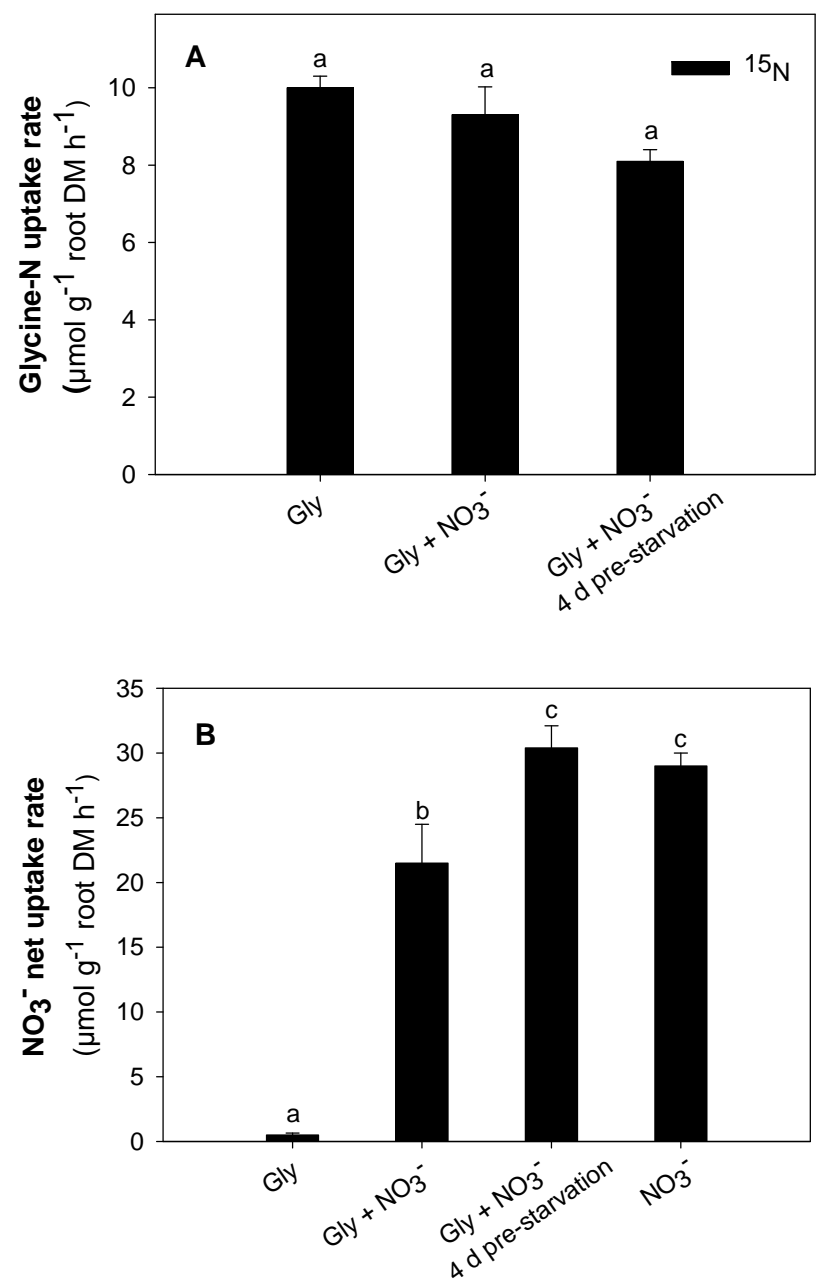

$\mathrm{N}$ treatment

Fig. 4. Glycine (A) and nitrate uptake (B) in wheat plants. ${ }^{15} \mathrm{~N}$, ${ }^{13} \mathrm{C}$ double-labelled glycine $(1 \mathrm{mM})$ was applied during a 3-day period with or without $3 \mathrm{mM} \mathrm{NO}_{3}^{-}$to hydroponically grown wheat plants pre-cultivated on $\mathrm{NO}_{3}^{-}$. Data are means $\pm \mathrm{SE}(n=4)$ obtained in Experiment II and letters indicate significant differences at $P=0.05$.

Thornton and Robinson, 2005) although in some cases this may not appear (Rodgers and Barneix, 1993).

The interaction between root uptake of inorganic and organic $\mathrm{N}$ forms reflects a feed-back repression in which the amino acid glutamine represents an important signal for the shoot to communicate $\mathrm{N}$ status to the roots, thereby enabling plants to regulate their rate of $\mathrm{N}$ uptake to accommodate for $\mathrm{N}$ demand during plant growth (Girin et al., 2007; Nazoa et al., 2003). Nitrate starvation may relieve this feed-back repression (Krapp et al., 1998) but did not lead to increased uptake of glycine or nitrate in the present work (Fig. 4). The feed-back repression is primarily targeted at transport proteins involved in $\mathrm{NO}_{3}^{-}$and $\mathrm{NH}_{4}^{+}$uptake, explaining why glycine uptake may not be affected to the same extent.
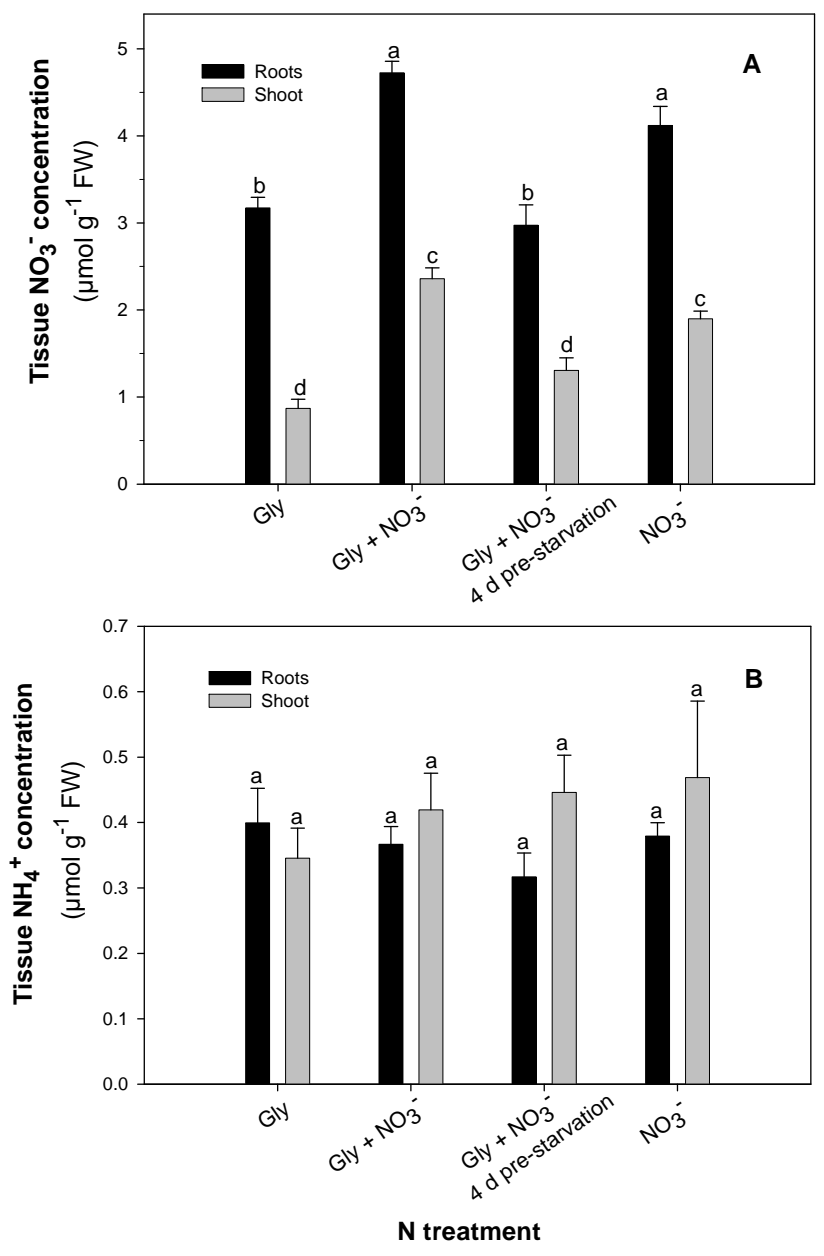

Fig. 5. Tissue $\mathrm{NO}_{3}^{-}$(A) and $\mathrm{NH}_{4}^{+}(\mathbf{B})$ in wheat plants pre-cultivated on $\mathrm{NO}_{3}^{-}$and subsequently applied glycine $(1 \mathrm{mM})$ during a 3-day period with or without $3 \mathrm{mM} \mathrm{NO}_{3}^{-}$. Data are means $\pm \mathrm{SE}(n=4)$ obtained in Experiment II and letters indicate significant differences at $P=0.05$.

Despite being taken up at a high rate, amino acids cannot constitute the sole $\mathrm{N}$ supply without leading to growth depression (Fig. 7). This may reflect bottlenecks in the rate at which nitrogen is transferred to other essential amino acids via deamination and or transamination. In addition, signalling pathways controlling phytohormone balance may be impeded causing growth inhibition (Krouk et al., 2011). More information is needed on growth responses of plants to mixtures of amino acids in concentrations typically present in soil solution.

\subsection{Fate of absorbed $\mathrm{C}$ and $\mathrm{N}$ in the plant}

The ratio between excess ${ }^{13} \mathrm{C}$ and ${ }^{15} \mathrm{~N}$ in roots and shoots was significantly lower than the theoretical values of 2.5 and 2 in glutamine and glycine (Fig. 1). It has been argued that if the enrichment of ${ }^{13} \mathrm{C}$ and ${ }^{15} \mathrm{~N}$ follows a liner 

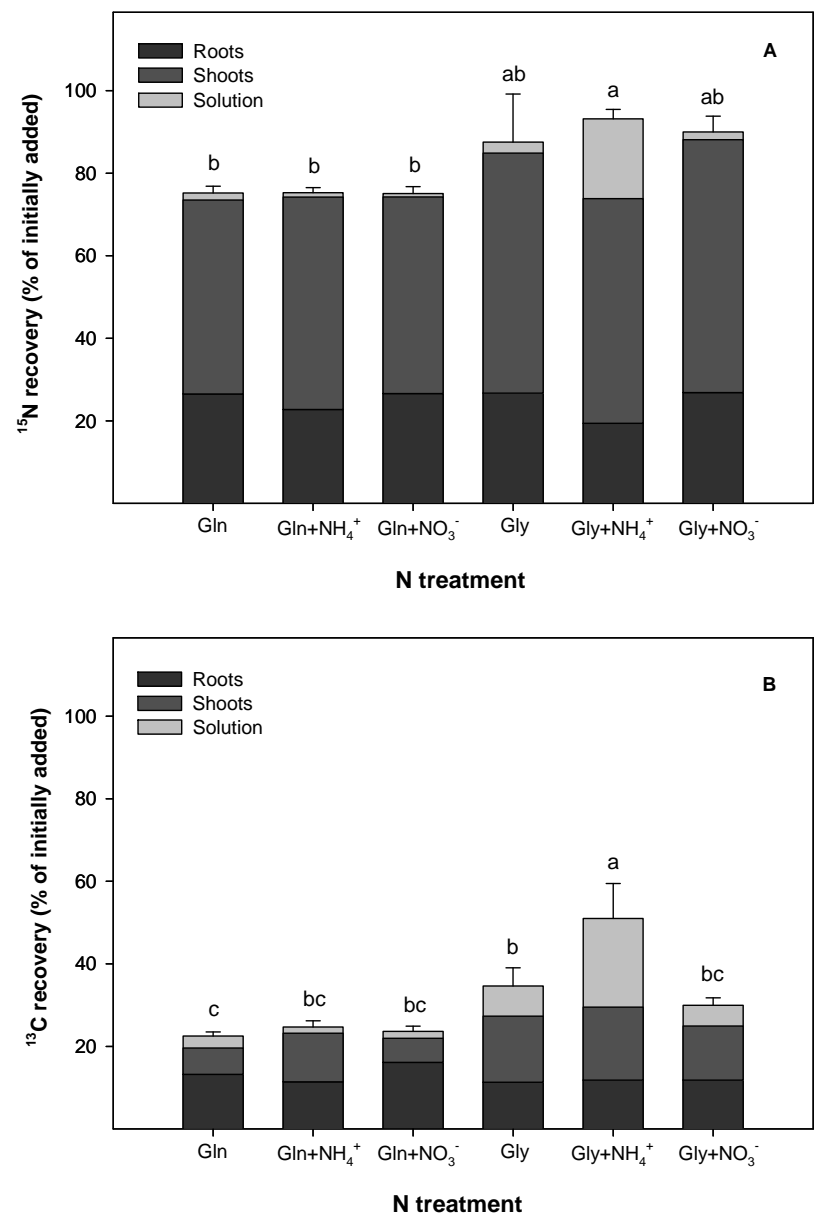

Fig. 6. Recoveries in plant roots, plant shoots and solution based on plant and solution analyses in Experiment I: (A) ${ }^{15} \mathrm{~N}$; (B) ${ }^{13} \mathrm{C}$. Data are means $\pm \mathrm{SE}$, error bars indicate cumulative $\mathrm{SE}(n=4)$ and letters significant differences at $P=0.05$.

relationship upon exposure to double-labelled amino acids, then the amino acids have been absorbed as intact molecules (Jones et al., 2005). However, some of the absorbed amino acid $\mathrm{C}$ will always be lost in the form of $\mathrm{CO}_{2}$ produced during deamination and breakdown of the $\mathrm{C}$ skeleton in the TCA cycle (Nasholm and Persson, 2001) or in processes related to photorespiration (Bauwe et al., 2010). In wheat plants this may amount to $60-80 \%$ of the absorbed amino acid C (Hill et al., 2011), agreeing with the losses reported in our study (Fig. 6). Substantial amounts of ${ }^{15} \mathrm{~N}$ can be lost from plant shoots (Schjoerring et al., 1989). These losses are typically highest towards plant maturation and may partly be due to $\mathrm{N}$ volatilization (Schjoerring et al., 2002; Sommer et al., 2004). However, the gaseous $\mathrm{N}$ losses from the foliage generally amount to only $1-5 \%$ of the $\mathrm{N}$ present in the plant, i.e. being considerably lower than $\mathrm{C}$ losses due to respiration. A lower ${ }^{13} \mathrm{C}:{ }^{15} \mathrm{~N}$ excess ratio does therefore not necessarily imply that amino acids were not taken up in intact form as also concluded by Schimel and Chapin (1996).

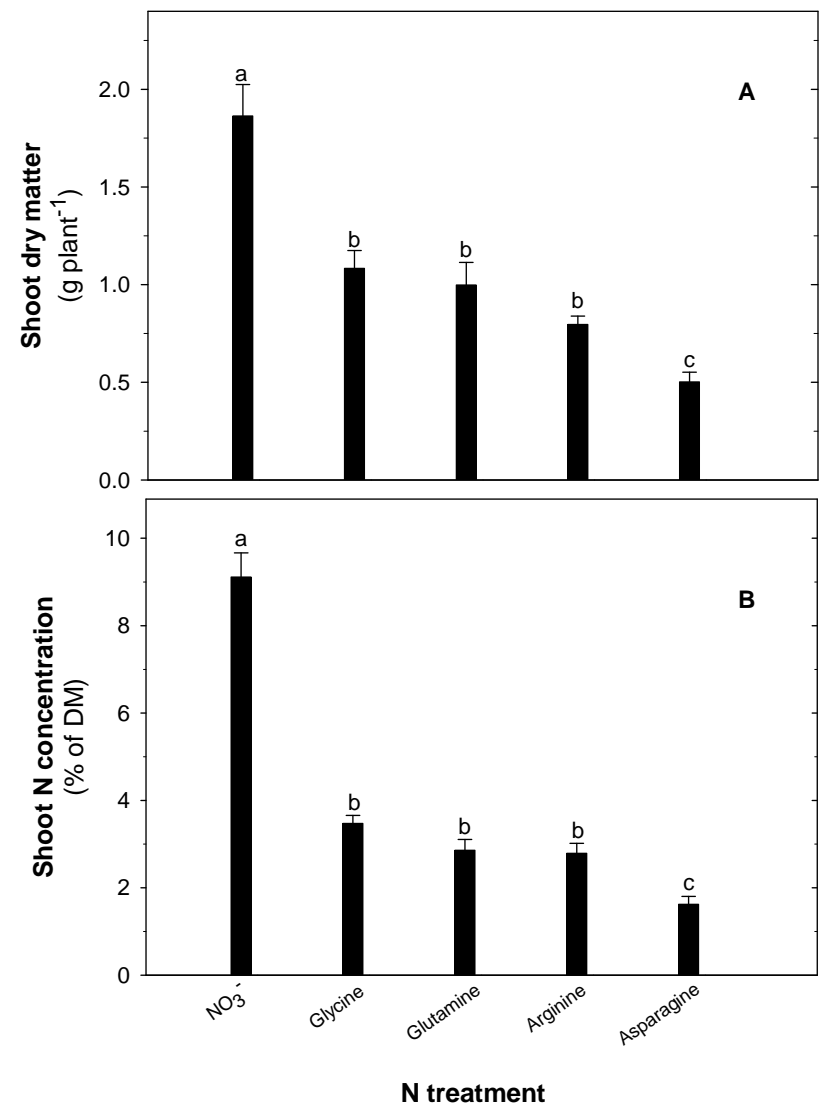

Fig. 7. Growth (A) and N concentration (B) of wheat plants supplied different amino acids as sole $\mathrm{N}$ source during a 17-day period in Experiment III. Data are mean values \pm SE $(n=4)$ and letters indicate significant differences at $P=0.05$.

Lower excess ${ }^{13} \mathrm{C}:{ }^{15} \mathrm{~N}$ ratios in plant tissues relative to applied amino acids might also result from deamination of amino acids before uptake, followed by uptake of inorganic ${ }^{15} \mathrm{~N}$. It does not seem likely that this process contributed significantly in our experiments, because only a few percentages of the ${ }^{13} \mathrm{C}$ were recovered in solution at the end of the experiment (Fig. 6). If the amino acids had been decomposed by microorganisms and the $\mathrm{N}$ released in inorganic form to the solution and subsequently taken up by the roots, a significant portion of the labelled $\mathrm{C}$ would have remained in the bacteria without being lost by respiration during the 3 day experimental period. The utilization efficiency of easily decomposable substrates typically varies between $0.4-0.7$ within the first days of decomposition (Parton et al., 1987; Steinweg et al., 2008; Thiet et al., 2006). This means that the amount of $\mathrm{C}$ lost by microbial respiration would be roughly similar to the amount retained in the microbial biomass. Consequently, taking into account the fact that only a few percentage of ${ }^{13} \mathrm{C}$ was recovered in the solution at the end of the $60-\mathrm{h}$ experimental period (Fig. 6), losses of $\mathrm{C}$ following microbial decomposition are only likely to have been responsible for 
a few percentages of the unrecovered ${ }^{13} \mathrm{C}$. Our assumption that the majority of the ${ }^{13} \mathrm{C}$ loss occurred after uptake of intact amino acids is further corroborated by the fact that the growth of plants exposed to amino acids as the sole $\mathrm{N}$ source was more than $50 \%$ reduced (Fig. 7) which would not have been the case if a substantial deamination in the nutrient solution had made $\mathrm{NH}_{4}^{+}$available as $\mathrm{N}$ source. Finally, amino acids are chemically very stable in water and would not deaminate spontaneously under the experimental conditions we applied.

The transport of amino acids from roots to shoots in plants is dominated by the amides glutamine and asparagine (Finnemann and Schjoerring, 1999; Harrison et al., 2000). Before being utilized as a N-source, a substantial part of the glycine absorbed by roots is therefore probably deaminated and channeled into amide synthesis, a process accompanied by release and re-assimilation of $\mathrm{NH}_{4}^{+}$. Glutamine may on the other hand be transported directly to shoots and utilized directly as an $\mathrm{N}$ source in the glutamate synthase-glutamine synthetase cycle. Alternatively, a glutamine transaminase may transfer the amino nitrogen to glycine or other amino acids (Joy, 1988). These amino acids may act as substrates for aminotransferases transferring the amino group to glyoxalate, thereby forming glycine which enters the photorespiratory pathway, resulting in release of $\mathrm{CO}_{2}$ and $\mathrm{NH}_{4}^{+}$(Bauwe et al., 2010). The fact that the excess ${ }^{13} \mathrm{C}:{ }^{15} \mathrm{~N}$ ratio was much lower in shoots compared to roots (Fig. 2) suggests that photorespiration may have played an important role in the assimilation of the $\mathrm{N}$ derived from the absorbed amino acids. Despite the release of $\mathrm{NH}_{4}^{+}$in the various metabolic processes involved in processing the absorbed amino acids, plants fed with glycine or glutamine did not contain elevated tissue $\mathrm{NH}_{4}^{+}$levels in neither roots nor shoots (Fig. 5). The capacity for re-assimilation of the generated $\mathrm{NH}_{4}^{+}$was thus not exceeded.

\subsection{Methodological aspects}

Two different methods, viz. stable isotope labelling with ${ }^{15} \mathrm{~N}$ ${ }^{13} \mathrm{C}$ amino acids and $\mathrm{NO}_{3}^{-} / \mathrm{NH}_{4}^{+}$depletion in the nutrient solution, were used to measure the separate contribution of organic and inorganic $\mathrm{N}$ sources to total plant $\mathrm{N}$ acquisition. Technically, the two methods differ in that with the first plants are harvested destructively at the end of the experimental period and subsequently analysed to obtain the uptake of the isotopically labelled compound, while with the second the nutrient solution in the root medium is sampled and analysed at different time intervals to determine the rate of solute removal by the roots. However, the two methods basically reflect the same underlying process viz. root uptake, and they will give similar results, as proven by Persson and Nasholm (2002), provided that other experimental and analytical factors are not interfering. Uptake rates of isotopically labelled amino acids might be underestimated if $\mathrm{N}$ losses occur during their assimilation in the plant, while on the other hand inorganic $\mathrm{N}$ uptake rate could be overestimated if there were $\mathrm{N}$ losses from the solution via e.g. volatilization. As discussed in Sect. 4.2 we do not consider these sources of error to have had a major impact on our results. Rasmussen and Kuzyakov (2009) and Rasmussen et al. (2010) used ${ }^{14} \mathrm{C} /{ }^{13} \mathrm{C} /{ }^{15} \mathrm{~N}$ triple-labelling to show that the simultaneous uptake of inorganic $\mathrm{C}$ interfered with root uptake of dual-labelled organic N. Unfortunately, a similar methodological option is not available for $\mathrm{N}$ because the only isotope that can be implemented is ${ }^{15} \mathrm{~N}$. The radio-isotope ${ }^{13} \mathrm{~N}$ with a half-life just below $10 \mathrm{~min}$ has been used for measurement of short-term uni-directional fluxes in plant roots (Ter Steege et al., 1998) but cannot be used in studies that also aim at revealing interactions associated with $\mathrm{N}$ assimilation and growth responses, which are manifested over a period of time longer than a few minutes or hours. There is a methodological challenge in proving the uptake of intact amino acids in experiments where their uptake is studied over an extended period of time. Persson and Nasholm (2002) used different metabolic inhibitors to prevent assimilation of the absorbed amino acids in order to analyse their accumulation inside the plant. However, this approach may lead to secondary feedback processes affecting the absorption of both inorganic and organic $\mathrm{N}$ forms.

\section{Conclusions}

It is concluded that amino acids can constitute a significant $\mathrm{N}$ source for wheat plants and that there is an interaction between the uptake of inorganic and organic N. Glycine uptake is not down-regulated in the presence of $\mathrm{NO}_{3}^{-}$, while $\mathrm{NO}_{3}^{-}$ uptake is reduced in the presence of glycine. Nitrogen prestarvation appears to counteract the down regulation of $\mathrm{NO}_{3}^{-}$ uptake in the presence of glycine. The ${ }^{13} \mathrm{C}:{ }^{15} \mathrm{~N}$ excess ratio is lower in shoots than in roots and is also lower than in the provided source of double-labelled amino acid, reflecting higher $\mathrm{C}$ losses via respiratory processes compared to $\mathrm{N}$ losses. The observed interactions between root absorption of inorganic and organic $\mathrm{N}$ forms have implications for further assessment of the contribution of organic $\mathrm{N}$ compounds to plant $\mathrm{N}$ nutrition.

Acknowledgements. The work was supported financially by the European Union Framework Programme 6 as part of the Integrated Project NitroEurope (www.nitroeurope.eu).

Edited by: P. Cellier 


\section{References}

Bauwe, H., Hagemann, M., and Fernie, A. R.: Photorespiration: players, partners and origin, Trends Plant Sci., 15, 330-336, 2010.

Biernath, C., Fischer, H., and Kuzyakov, Y.: Root uptake of Ncontaining and $\mathrm{N}$-free low molecular weight organic substances by maize: ${ }^{14} \mathrm{C}^{15} \mathrm{~N}$ tracer study, Soil Biol. Biochem., 40, 2237-2245, 2008.

Brooks, P. D., Stark, J. M., McInteer, B. B., and Preston, T.: Diffusion method to prepare soil extracts for automated nitrogen-15 analysis, Soil Sci. Soc. Am. J., 53, 1707-1711, 1989.

Christou, M., Avramides, E. J., Roberts, J. P., and Jones, D. L.: Dissolved organic nitrogen in contrasting agricultural ecosystems, Soil Biol. Biochem., 37, 1560-1563, 2005.

El-Naggar, A., de Neergaard, A., El-Araby, A., and Høgh-Jensen, H.: Simultaneous Uptake of Multiple Amino Acids by Wheat, J. Plant Nutr., 32, 725-740, 2009.

Finnemann, J. and Schjoerring, J. K.: Translocation of $\mathrm{NH}_{4}^{+}$in oilseed rape plants in relation to glutamine synthetase isogene expression and activity, Physiol. Plantarum, 105, 469-477, 1999.

Ge, T., Song, S., Roberts, P., Jones, D. L., Huang, D., and Iwasaki, K.: Amino acids as a nitrogen source for tomato seedlings: The use of dual-labeled $\left({ }^{13} \mathrm{C},{ }^{15} \mathrm{~N}\right)$ glycine to test for direct uptake by tomato seedlings, Environ. Exp. Bot., 66, 357-361, 2009.

Girin, T., Lejay, L., Wirth, J., Widiez, T., Palenchar, P. M., Nazoa, P., Touraine, B., Gojon, A., and Lepetit, M.: Identification of a 150-bp cis-acting element of the AtNRT2.1 promoter involved in the regulation of gene expression by the $\mathrm{N}$ and $\mathrm{C}$ status of the plant, Plant Cell Environ., 30, 1366-1380, 2007.

Glass, A. D. M.: Nitrate uptake by plant roots, Botany, 87, 659-667, 2009.

Harrison, J., Brugiere, N., Phillipson, B., Ferrario-Mery, S., Becker, T., Limami, A., and Hirel, B.: Manipulating the pathway of ammonia assimilation through genetic engineering and breeding: consequences to plant physiology and plant development, Plant Soil, 221, 81-93, 2000.

Henry, H. A. L. and Jefferies, R. L.: Plant amino acid uptake, soluble $\mathrm{N}$ turnover and microbial $\mathrm{N}$ capture in soils of a grazed Arctic salt marsh, J. Ecol., 91, 627-636, 2003.

Hill, P. W., Quilliam, R. S., DeLuca, T. H., Farrar, J., Farrell, M., Roberts, P., Newsham, K. K., Hopkins, D. W., Bardgett, R. D., and Jones, D. L.: Acquisition and Assimilation of Nitrogen as Peptide-Bound and D-Enantiomers of Amino Acids by Wheat, PLoS ONE, 6, e19220, doi:10.1371/journal.pone.0019220, 2011.

Hirner, A., Ladwig, F., Stransky, H., Okumoto, S., Keinath, M., Harms, A., Frommer, W. B., and Koch, W.: Arabidopsis LHT1 is a high-affinity transporter for cellular amino acid uptake in both root epidermis and leaf mesophyll, Plant Cell, 18, 1931-1946, 2006.

Jamtgard, S., Näsholm, T., and Huss-Danell, K.: Characteristics of amino acid uptake in barley, Plant Soil, 302, 221-231, 2008.

Jamtgard, S., Näsholm, T., and Huss-Danell, K.: Nitrogen compounds in soil solutions of agricultural land, Soil Biol. Biochem., 42, 2325-2330, 2010.

Jones, D. L., Owen, A. G., and Farrar, J. F.: Simple method to enable the high resolution determination of total free amino acids in soil solutions and soil extracts, Soil Biol. Biochem., 34, 1893$1902,2002$.
Jones, D. L., Healey, J. R., Willett, V. B., Farrar, J. F., and Hodge, A.: Dissolved organic nitrogen uptake by plants - an important N uptake pathway?, Soil Biol. Biochem., 37, 413-423, 2005.

Joy, K. W.: Ammonia, glutamine, and asparagine: a carbonnitrogen interface, Can. J. Botany, 66, 2103-2109, 1988.

Kielland, K.: Amino Acid Absorption by Arctic Plants: Implications for Plant Nutrition and Nitrogen Cycling, Ecology, 75, 2373-2383, 1994

Krapp, A., Fraisier, V., Scheible, W. R., Quesada, A., Gojon, A., Stitt, M., Caboche, M., and Daniel-Vedele, F.: Expression studies of $N r t 2: 1 N p$, a putative high-affinity nitrate transporter: evidence for its role in nitrate uptake, Plant J., 14, 723-731, 1998.

Krouk, G., Ruffel, S., Gutierrez, R. A., Gojon, A., Crawford, N. M., Coruzzi, G. M., and Lacombe, B. T.: A framework integrating plant growth with hormones and nutrients, Trends Plant Sci., 16, 178-182, 2011.

Lee, Y. H., Foster, J., Chen, J., Voll, L. M., Weber, A. P. M., and Tegeder, M.: AAP1 transports uncharged amino acids into roots of Arabidopsis, Plant J., 50, 305-319, 2007.

Lipson, D. A. and Nasholm, T.: The unexpected versatility of plants: organic nitrogen use and availability in terrestrial ecosystems, Oecologia, 128, 305-316, 2001.

Lipson, D. A., Raab, T. K., Schmidt, S. K., and Monson, R. K.: Variation in competitive abilities of plants and microbes for specific amino acids, Biol. Fert. Soils, 29, 257-261, 1999.

Nasholm, T. and Persson, J.: Plant acquisition of organic nitrogen in boreal forests, Physiol. Plantarum, 111, 419-426, 2001.

Nasholm, T., Ekblad, A., Nordin, A., Giesler, R., Hogberg, M., and Hogberg, P.: Boreal forest plants take up organic nitrogen, Nature, 392, 914-916, 1998.

Nasholm, T., Huss-Danell, K., and Hogberg, P.: Uptake of organic nitrogen in the field by four agriculturally important plant species, Ecology, 81, 1155-1161, 2000.

Nasholm, T., Huss-Danell, K., and Hogberg, P.: Uptake of glycine by field grown wheat, New Phytol., 150, 59-63, 2001.

Nasholm, T., Kielland, K., and Ganeteg, U.: Uptake of organic nitrogen by plants, New Phytol., 182, 31-48, 2009.

Nazoa, P., Vidmar, J. J., Tranbarger, T. J., Mouline, K., Damiani, I., Tillard, P., Zhuo, D., Glass, A. D. M., and Touraine, B.: Regulation of the nitrate transporter gene AtNRT2.1 in Arabidopsis thaliana: responses to nitrate, amino acids and developmental stage, Plant Mol. Biol., 52, 689-703, 2003.

Parton, W. J., Schimel, D. S., Cole, C. V., and Ojima, D. S.: Analysis of factors controlling soil organic matter levels in Great Plains grasslands, Soil Sci. Soc. Am. J., 51, 1173-1179, 1987.

Persson, J. and Nasholm, T.: Regulation of amino acid uptake in conifers by exogenous and endogenous nitrogen, Planta, 215, 639-644, 2002.

Rasmussen, J. and Kuzyakov, Y.: Carbon isotopes as proof for plant uptake of organic nitrogen: Relevance of inorganic carbon uptake, Soil Biol. Biochem., 41, 1586-1587, 2009.

Rasmussen, J., Sauheitl, L., Eriksen, J., and Kuzyakov, Y.: Plant uptake of dual-labeled organic $\mathrm{N}$ biased by inorganic $\mathrm{C}$ uptake: Results of a triple labeling study, Soil Biol. Biochem., 42, 524527, 2010.

Rodgers, C. O. and Barneix, A. J.: The effect of amino acids and amides on the regulation of nitrate uptake by wheat seedlings, J. Plant Nutr., 16, 337-348, 1993. 
Schimel, J. P. and Chapin, F. S. I.: Tundra Plant Uptake of Amino Acid and $\mathrm{NH}_{4}^{+}$Nitrogen in Situ: Plants Complete Well for Amino Acid N, Ecology, 77, 2142-2147, 1996.

Schjoerring, J. K., Nielsen, N. E., Jensen, H. E., and Gottschau, A.: Nitrogen losses from field-grown spring barley plants as affected by rate of nitrogen application, Plant Soil, 116, 167-175, 1989.

Schjoerring, J. K., Husted, S., Mack, G., and Mattsson, M.: The regulation of ammonium translocation in plants, J. Exp. Bot., 53, 883-890, 2002.

Sommer, S. G., Schjoerring, J. K., and Denmead, O. T.: Ammonia emission from mineral fertilizers and fertilized crops, Adv. Agron., 82, 558-622, 2004.

Steinweg, J. M., Plante, A. F., Conant, R. T., Paul, E. A., and Tanaka, D. L.: Patterns of substrate utilization during long-term incubations at different temperatures, Soil Biol. Biochem., 40, 2722-2728, 2008.

Streeter, T. C., Bol, R., and Bardgett, R. D.: Amino acids as a nitrogen source in temperate upland grasslands: The use of dual labelled $\left({ }^{13} \mathrm{C},{ }^{15} \mathrm{~N}\right)$ glycine to test for direct uptake by dominant grasses, Rapid Commun. Mass Sp., 14, 1351-1355, 2000.

Svennerstam, H., Ganeteg, U., and Nasholm, T.: Root uptake of cationic amino acids by Arabidopsis depends on functional expression of amino acid permease 5, New Phytol., 180, 620-630, 2008 .
Ter Steege, M. W., Stulen, I., Wiersema, P. K., Paans, A. J. M., Vaalburg, W., Kuiper, P. J. C., and Clarkson, D. T.: Growth requirement for $\mathrm{N}$ as a criterion to assess the effects of physical manipulation on nitrate uptake fluxes in spinach, Physiol. Plantarum, 103, 181-192, 1998.

Thiet, R. K., Frey, S. D., and Six, J.: Do growth yield efficiencies differ between soil microbial communities differing in fungal:bacterial ratios? Reality check and methodological issues, Soil Biol. Biochem., 38, 837-844, 2006.

Thornton, B.: Uptake of glycine by non-mycorrhizal Lolium perenne, J. Exp. Bot., 52, 1315-1322, 2001.

Thornton, B.: Inhibition of nitrate influx by glutamine in Lolium perenne depends upon the contribution of the HATS to the total influx, J. Exp. Bot., 55, 761-769, 2004.

Thornton, B. and Robinson, D.: Uptake and assimilation of nitrogen from solutions containing multiple N sources, Plant Cell Environ., 28, 813-821, 2005.

Yamagata, M. and Ae, N.: Direct acquisition of organic nitrogen by crops, JARQ-Jpn Agr. Res. Q., 1, 15-21, 1999. 